\title{
Efficiency of inoculant with Azospirillum brasilense on the growth and yield of second-harvest maize ${ }^{1}$
}

\author{
Raoni Ribeiro Guedes Fonseca Costa ${ }^{2}$, Gerciene da Silva Ferreira Quirino ${ }^{2}$, \\ Daniela Cristina de Freitas Naves ${ }^{2}$, Charles Barbosa Santos ${ }^{3}$, Ana Flávia de Souza Rocha ${ }^{2}$
}

\section{ABSTRACT}

The misuse of fertilizers has become a growing concern in terms of agricultural and environmental sustainability. One alternative to reduce the impact of chemical fertilizers is the use of inoculants containing nitrogen-fixing and plant growth promoting bacteria. This study aimed at evaluating the effects of an inoculant with Azospirillum brasilense on the growth and yield of secondharvest maize. The experimental design was randomized blocks with three replications, in a $3 \times 5$ factorial scheme. The treatments consisted of three inoculation methods (control without inoculation, seed inoculation and leaf-sprayed inoculation at the V4 stage) and five cover $\mathrm{N}$-fertilization doses $(0 \%, 25 \%, 50 \%, 75 \%$ and $100 \%$, with the $100 \%$ dose corresponding to $50 \mathrm{~kg} \mathrm{ha}^{-1}$ of $\mathrm{N}$ as urea). Inoculated plants showed a greater growth for height (9.5\% and $16 \%)$, stem dry biomass (49\% and $6.75 \%$ ) and root dry biomass (123\% and $97 \%$ ), respectively for seed inoculation and spraying, as well as increases in ear size $(8 \%)$, chlorophyll content (4\%), 1,000-grain weight (12\%) and grain yield (29\%), when compared to non-inoculated plants. The effects of $\mathrm{N}$ doses were only significant for 1,000-grain weight and grain yield $\left(\mathrm{kg} \mathrm{ha}^{-1}\right)$, with seed inoculation providing a higher yield for second-harvest maize.

KEY-WORDS: Zea mays; nitrogen-fixing bacteria; nitrogen fertilization.

\section{INTRODUCTION}

The high cost of chemical fertilizers and concerns about more sustainable and less polluting agriculture have led to increasing interest in the use of inoculants containing bacteria that promote plant growth and enhance crop yield (Hungria et al. 2010).

Plant growth promoting bacteria are beneficial bacteria found in the rhizosphere, though they can

\section{RESUMO}

Eficiência de inoculante com Azospirillum brasilense no crescimento e produtividade de milho de segunda safra

O uso inadequado de fertilizantes tem sido uma preocupação crescente, em relação à sustentabilidade agrícola e ambiental. Uma das alternativas para reduzir o impacto de fertilizantes químicos é o uso de inoculantes contendo bactérias fixadoras de nitrogênio e promotoras de crescimento vegetal. Objetivou-se avaliar os efeitos de um inoculante à base de Azospirillum brasilense sobre as características de crescimento e produtividade do milho de segunda safra. O delineamento experimental foi em blocos casualizados, com três repetições, em esquema fatorial $3 \times 5$. Os tratamentos incluíram três níveis de inoculação (controle sem inoculante, inoculação na semente e aplicação foliar do inoculante no estágio V4) e cinco doses de adubação nitrogenada em cobertura ( $0 \%, 25 \%, 50 \%$, $75 \%$ e $100 \%$, sendo a dose de $100 \%$ correspondente a $50 \mathrm{~kg} \mathrm{ha}^{-1}$ de $\mathrm{N}$ na forma de ureia). Os tratamentos que receberam inoculante apresentaram maior crescimento em altura (9,5\% e 16\%), biomassa seca do colmo (49\% e 6,75\%) e biomassa seca da raiz (123\% e $97 \%$ ), respectivamente para inoculante na semente e pulverizado, bem como incremento no tamanho da espiga ( $8 \%$ ), teor de clorofila (4 \%), massa de 1.000 grãos (12 \%) e produção de grãos (29 \%), em comparação às plantas não inoculadas. Os efeitos das doses de $\mathrm{N}$ foram significativos apenas para massa de 1.000 grãos e produtividade de grãos $\left(\mathrm{kg} \mathrm{ha}^{-1}\right)$, verificando-se que a inoculação na semente proporcionou maior produtividade no milho de segunda safra.

PALAVRAS-CHAVE: Zea mays; bactérias fixadoras de nitrogênio; adubação nitrogenada.

also be found colonizing roots and internal tissues. The capacity of these bacteria to fix nitrogen allows them to promote plant growth (Hungria et al. 2010) by producing phytohormones such as indole-acetic acid, cytokinins, gibberellins and ethylene (Moreira et al. 2010). Within this group, the genus Azospirillum stands out. These bacteria improve conditions for development of root system as they synthesize phytohormones, allowing absorption of more water and 
nutrients, as well as providing more tolerance against drought and salinity stresses (Bashan et al. 2004).

However, the results of the interaction between these bacteria and maize, in terms of agronomic potential, $\mathrm{N}$ fixation and growth promotion, depend on many biotic and environmental factors, including plant genotype, the microbiological community in the soil and nitrogen availability (Roesch et al. 2006). According to Hungria et al. (2010), it is estimated that the use of inoculants containing selected strains of Azospirillum brasilense may save approximately US\$ 2 billion in chemical fertilizers, allowing reduction in transport costs, and leading to a reduction in pollution resulting from the production and use of $\mathrm{N}$-fertilizers.

Therefore, this study aimed at evaluating the effects of seed inoculation and leaf-spraying with Azospirillum brasilense inoculants in combination with increasing doses of $\mathrm{N}$-fertilizer (urea) on the growth and yield of second-harvest maize.

\section{MATERIAL AND METHODS}

The experiment was performed in Quirinópolis $\left(18^{\circ} 26^{\prime} 52^{\prime \prime} \mathrm{S}, 50^{\circ} 27^{\prime} 07^{\prime \prime} \mathrm{W}\right)$, in the southern mesoregion of the Goiás State, Brazil. The region is located in a hot, tropical sub-humid zone, which has two distinct seasons and experiences significant annual variations in humidity, temperature and rainfall. It is categorized as hot and humid (AW), with rainy summers and dry winters. The mean year-round temperature is $21^{\circ} \mathrm{C}$ (Santos et al. 2010).

A complete randomized blocks design with three replications, in a $3 \times 5$ factorial scheme, was used to evaluate the factors $A$. brasilense inoculation and nitrogen concentration.
Three inoculation levels were tested: control without inoculation, seed inoculation and leafsprayed inoculation at stage V4. Each inoculation level was tested with five different cover doses of chemical $\mathrm{N}$ (urea) $(0 \%, 25 \%, 50 \%, 75 \%$ and $100 \%$, with the $100 \%$ dose corresponding to $50 \mathrm{~kg} \mathrm{ha}^{-1} \mathrm{~N}$ applied at stage V6).

According to Embrapa (2013), the soil in the experimental area is classified as a Distroferric Red Latosol (Oxisol) and is composed of $560 \mathrm{~g} \mathrm{~kg}^{-1}$ of clay, $75 \mathrm{~g} \mathrm{~kg}^{-1}$ of silt and $365 \mathrm{~g} \mathrm{~kg}^{-1}$ of sand. The chemical characteristics of the $0-20 \mathrm{~cm}$ soil layer prior to planting were: $\mathrm{pH}$ in water $=5.1$; $\mathrm{Ca}=1.90 \mathrm{cmol}_{\mathrm{c}} \mathrm{dm}^{-3} ; \mathrm{Mg}=0.88 \mathrm{cmol}_{\mathrm{c}} \mathrm{dm}^{-3}$; $\mathrm{Al}=0.06 \mathrm{cmol}_{\mathrm{c}} \mathrm{dm}^{-3} ; \mathrm{Al}+\mathrm{H}=4.8 \mathrm{cmol}_{\mathrm{c}}^{\mathrm{c}} \mathrm{dm}^{-3}$; $\mathrm{CTC}=7.84 \mathrm{cmol}_{\mathrm{c}} \mathrm{dm}^{-3} ; \mathrm{K}=102 \mathrm{mg} \mathrm{dm}^{-3} ; \mathrm{P}=$ $4.9 \mathrm{mg} \mathrm{dm}^{-3} ; \mathrm{Cu}=3.70 \mathrm{mg} \mathrm{dm}^{-3} ; \mathrm{Zn}=2.0 \mathrm{mg} \mathrm{dm}^{-3}$; $\mathrm{Fe}=81.0 \mathrm{mg} \mathrm{dm}{ }^{-3}$; and M.O. $=16.5 \mathrm{~g} \mathrm{dm}^{-3}$. Throughout the experiment, the mean monthly rainfall was monitored on a daily basis (Figure 1).

The simple maize hybrid 30S31 (Pioneer) was sown on February 17th, 2014, using a mechanical seeder. The area was prepared by eliminating invasive plants through the application of 1,458 $\mathrm{g} \mathrm{ha}^{-1}$ of glyphosate. For planting, $227 \mathrm{~kg} \mathrm{ha}^{-1}$ of the formulation 10-15-15 $\left(\mathrm{N}-\mathrm{P}_{2} \mathrm{O}_{5}-\mathrm{K}_{2} \mathrm{O}\right)$ were applied. The experimental plots consisted of 12 lines $12 \mathrm{~m}$ long, with $0.50 \mathrm{~m}$ between lines. Thirty-six seeds were sown per line in an attempt to establish a population of 60,000 plants $\mathrm{ha}^{-1}$. The inoculant used was Azototal, which contains Azospirillum brasilense strains Ab-V5 and Ab-V6 at a concentration of $2 \times 10^{8} \times$ cells $\mathrm{mL}^{-1}$. The dosage used to inoculate seeds was $100 \mathrm{~mL}$ per $25 \mathrm{~kg}$ of seeds, as per the manufacturer's technical recommendation. The leaf-inoculant spray was comprised of 5 doses $(500 \mathrm{~mL})$ of the inoculant diluted in $50 \mathrm{~L} \mathrm{ha}^{-1}$ of water.

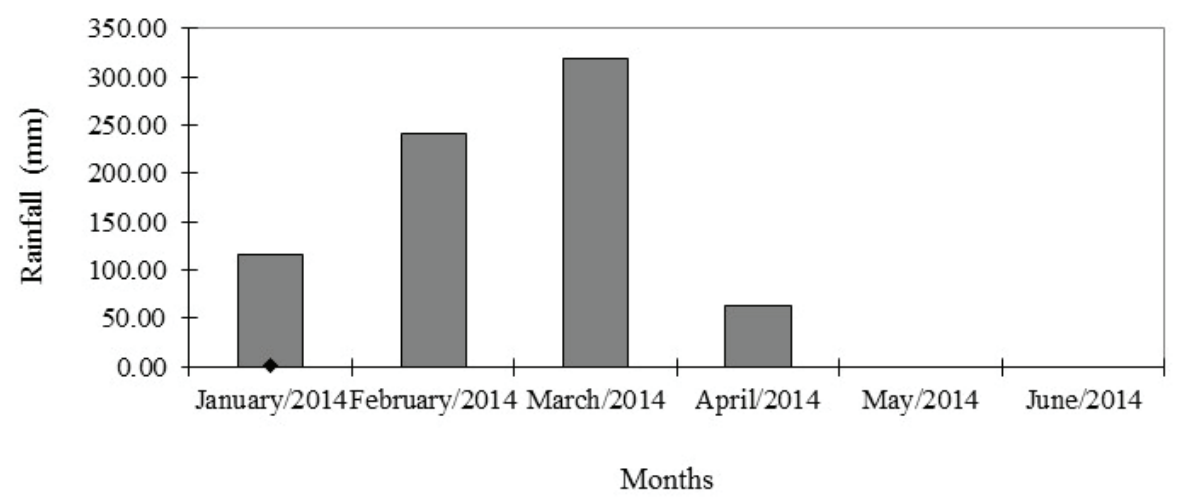

Figure 1. Mean rainfall observed from January through June 2014 (Quirinópolis, Goiás State, Brazil). 
Height $(\mathrm{cm})$ and stem diameter $(\mathrm{mm})$ data were collected at 30 (March 17th, 2014) and 60 (April 17th, 2014) days after sowing using a measuring tape and a digital caliper. During the same period, the chlorophyll content (SPAD units) of the upper third leaf was estimated using a digital chlorophyll meter (SPAD-502, Minolta, Osaka, Japan). Data were collected from five plants along four central lines in a $20 \mathrm{~m}^{2}$ working area within each plot.

Dried biomass from the roots and shoots of the plants were collected from the working area $\left(20 \mathrm{~m}^{2}\right)$ at 90 days after sowing. To determine dry biomass, maize plants were cut off close to the soil. The vegetative material was then chopped, subsampled and dried in a laboratory oven with forced air circulation at $65^{\circ} \mathrm{C}$, until a constant mass was obtained. When the harvest date was reached, at 135 days after sowing (June 28th, 2014), three cobs along a meter in the four central lines were randomly sampled in each plot to determine the length and 1,000-grain weight, as well as yield. Mean cob length $(\mathrm{cm})$ was determined using a ruler to measure from the cob base to its tip.

Yield was obtained using a mechanical strip, and grain weight was derived from the ears collected from the useful plot areas. The weight was converted to $\mathrm{kg} \mathrm{ha}^{-1}$ and corrected to $13 \%$ of humidity. The dataset was subjected to an analysis of variance using the Biostat 5.3 software (Ayres et al. 2007) and the means were compared using the Tukey test at $5 \%$. When significant difference was found in the $\mathrm{N}$ dosage interaction with inoculations, a regression analysis was carried out.

\section{RESULTS AND DISCUSSION}

Plant heights $(\mathrm{cm})$ at 30 and 60 days after sowing are shown in Table 1. There was no statistical difference in this stage of development for doses of mineral $\mathrm{N}$ at 60 days. However, significant effect was observed with $\mathrm{N}$ rates at 30 days for the treatment with leaf-spray inoculant from the dose of $50 \%$ N. Significant effect was observed with respect to inoculation with Azospirillum brasilense. On average, there was a $10 \%$ increase in the height of seed inoculated plants, if compared to other treatments at 60 days after sowing. This result surpassed that found by Kappes et al. (2013), who observed a $5.84 \%$ increase in the mean height of inoculated maize plants, when compared to the noninoculated control.

Studies have shown that Azospirillum stimulates the growth and yield of several plant species, many of which have great agronomic and ecological relevance (Hungria et al. 2010, Ramos et al. 2010, Kappes et al. 2013).

Cavallet et al. (2000) and Ramos et al. (2010) confirmed that nitrogen treated plants grew taller when seeds were inoculated with Azospirillum spp., if compared to the control. However, conflicting results are also found in the literature. For example, Dartora et al. (2013) and Lana et al. (2012) could not verify responses in height for plants inoculated with Azospirillum and fertilized with N. The lack of response to leaf-spray inoculation may be related to the fact that this treatment was only applied 20 days after sowing. At this point, plants may not have enough time to express the effect of the inoculation.

Table 1. Plant height measured at 30 and 60 days after sowing in a non-inoculated control maize plant and maize plants inoculated with Azospirillum brasilense strains Ab-V5 and Ab-V6 via seeds or leaf-spray inoculation at the V4 stage (Quirinópolis, Goiás State, Brazil, 2014).

\begin{tabular}{|c|c|c|c|c|c|}
\hline \multirow{3}{*}{ Inoculation } & \multicolumn{5}{|c|}{ Height (m) } \\
\hline & \multicolumn{5}{|c|}{$\mathrm{N}$ doses } \\
\hline & $0 \%$ & $25 \%$ & $50 \%$ & $75 \%$ & $100 \%$ \\
\hline \multicolumn{6}{|c|}{30 days after sowing } \\
\hline Seeds & $0.69 \mathrm{Aa}$ & $0.74 \mathrm{Aa}$ & $0.75 \mathrm{Aa}$ & $0.79 \mathrm{Aa}$ & $0.79 \mathrm{Aa}$ \\
\hline Leaf-spray & $0.62 \mathrm{Bb}$ & $0.66 \mathrm{Ba}$ & $0.70 \mathrm{Ba}$ & $0.68 \mathrm{Ba}$ & $0.68 \mathrm{Ba}$ \\
\hline Control & $0.63 \mathrm{Bb}$ & $0.62 \mathrm{Bb}$ & $0.65 \mathrm{Ba}$ & $0.68 \mathrm{Ba}$ & $0.68 \mathrm{Ba}$ \\
\hline \multicolumn{6}{|c|}{60 days after sowing } \\
\hline Seeds & $2.60 \mathrm{Aa}$ & $2.58 \mathrm{Aa}$ & $2.61 \mathrm{Aa}$ & $2.66 \mathrm{Aa}$ & $2.69 \mathrm{Aa}$ \\
\hline Leaf-spray & $2.49 \mathrm{Ba}$ & $2.45 \mathrm{Ba}$ & $2.45 \mathrm{Ba}$ & $2.46 \mathrm{Ba}$ & $2.46 \mathrm{Ba}$ \\
\hline Control & $2.45 \mathrm{Ba}$ & $2.41 \mathrm{Aa}$ & $2.46 \mathrm{Ba}$ & $2.49 \mathrm{Ba}$ & $2.42 \mathrm{Ba}$ \\
\hline
\end{tabular}

Means followed by the same uppercase letter in the column and lower case letter in the line do not significantly differ from each other by the Tukey test at $5 \%$. Inoculations were applied in combination with cover doses of mineral $\mathrm{N}$ at the V6 stage, where $100 \%$ equals $50 \mathrm{~kg} \mathrm{ha}^{-1}$ as urea. 
Regarding the shoot dry biomass, increases of $49 \%$ and $6.75 \%$ were respectively observed in the dry matter of the seed and leaf-spray inoculation, when compared to the control treatment (Table 2). The same behavior was observed for the dry biomass of the root systems, with increases of $123 \%$ and $97 \%$, respectively. The Tukey test did not reveal a significant effect $(5 \%)$ of $\mathrm{N}$ dosage on the production of mass in the form of shoot and root dry matter.

Barassi et al. (2008) observed increases in chlorophyll content, proline content in the shoots and roots, water content in the apoplast, as well as an improvement in hydraulic potential, elasticity of cell walls, biomass production and plant heights. An increase in the dry biomass of both the shoots and roots of the plant caused by Azospirilum was also found by Dalla Santa et al. (2004) and Domingues Neto et al. (2013). This later study recorded an $18-33 \%$ increase in the fresh mass of the shoot and root portions of the plant. When inoculation is

Table 2. Dry shoot and root biomass measured at 135 days after sowing for non-inoculated control and maize plants inoculated with Azospirillum brasilense strains AbV5 and Ab-V6 via seeds or leaf-spray at the V4 stage (Quirinópolis, Goiás State, Brazil, 2014).

\begin{tabular}{crrr}
\hline Trait & \multicolumn{1}{c}{ Seeds } & Leaf-spray & \multicolumn{1}{c}{ Control } \\
\hline Shoot biomass $(\mathrm{g})$ & $1,604.69 \mathrm{a}$ & $1,148.31 \mathrm{~b}$ & $1,075.62 \mathrm{~b}$ \\
Root biomass $(\mathrm{g})$ & $103.28 \mathrm{a}$ & $91.46 \mathrm{~b}$ & $46.29 \mathrm{c}$ \\
\hline
\end{tabular}

Means followed by the same letter in the line do not differ significantly from each other by the Tukey test at $5 \%$. Inoculations were applied in combination with cover doses of mineral $\mathrm{N}$ at the V6 stage, where $100 \%$ equals $50 \mathrm{~kg} \mathrm{ha}^{-1}$ as urea. associated with mineral nitrogen supply, an $80 \%$ higher yield in total dry matter (stem + leaves) can be produced, when compared to plants treated only with nitrogen fertilization (Ramos et al. 2010).

It is possible to observe a greater abundance and longer root lengths in the treatments inoculated with strains of Azospirillum brasiliense (Figure 2). Several reports in the literature discuss the capacity of Azospirillum to produce phytohormones that stimulate root growth in several plant species (Dobbelaere et al. 2001, Bashan et al. 2004, Corrêa et al. 2008, Hungria et al. 2010, Braccini et al. 2012). For example, according to Moreira et al. (2010), A. brasilense produces the components responsible for stimulating the growth of roots, including indoleacetic acid (AIA), gibberellins and cytokinins. Amore efficient root development provides many benefits, such as better nutrition and a higher tolerance to drought stress (Corrêa et al. 2008).

The results for stem diameter growth at 30 and 60 days after sowing are presented in Table 3. After 30 days, the seed-inoculated treatment had a higher stem diameter (on average $8 \%$ ), when compared with other treatments. However, no statistically significant difference was observed after 60 days.

Dartora et al. (2013) found that Azospirilum had a significant effect on the basal diameter of maize plants in the vegetative (V8) and reproductive (R3) stages. On the other hand, Dotto et al. (2010) did not verify this trend when evaluating the effects of Herbaspirillum seropedicae inoculations and $\mathrm{N}$ levels on the behavior of maize hybrids. The initial

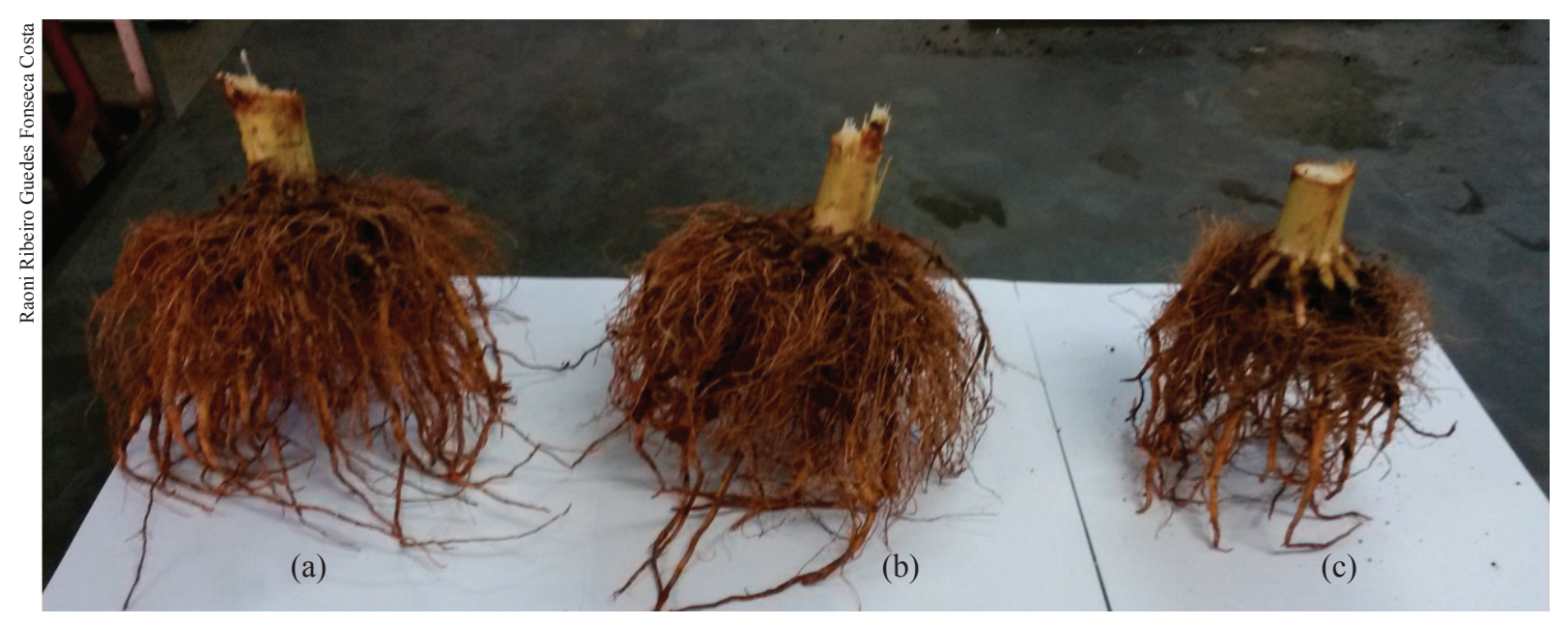

Figure 2. Root system development in the maize hybrid 30S31 (Pioneer): a) Azospirillum inoculated in the seed; b) leaf-spray inoculation at the V4 stage; c) control without an inoculant (Quirinópolis, Goiás State, Brazil, 2014). 
increase in the stem diameter of plants subjected to inoculation may be associated with the production of phytohormones (Moreira et al. 2010). Kappes et al. (2013) also observed an increase in mean stem diameter in response to the increase in $\mathrm{N}$ fertilization via leaf coverage; however, no effect of the inoculant was verified at 60 days after sowing.

No significant difference was observed in chlorophyll content among treatments, at 30 days after sowing (Table 4). However, the seed-inoculated treatment showed a higher chlorophyll content, if compared with the other treatments at 60 days after sowing, beginning with a $75 \% \mathrm{~N}$ dosage (37.5 $\left.\mathrm{kg} \mathrm{ha}^{-1}\right)$. Leaf chlorophyll content is used to predict the nutritional level of $\mathrm{N}$ in plants, and the content of this pigment is positively correlated with N content (Piekielek et al.1995). Kappes et al. (2013) also verified this effect, which was pronounced when cover doses of $90 \mathrm{~kg} \mathrm{ha}^{-1}$ of $\mathrm{N}$ were applied. The authors argued that the chlorophyll content responded to the increase in $\mathrm{N}$ because this nutrient participates directly in the biosynthesis of proteins and chlorophyll.

No significant impacts on ear size were observed for different $\mathrm{N}$ doses, independently of the treatment. However, there were significant differences among control and inoculation treatments (Table 4). On average, both the seed and leaf-spray inoculated treatments showed longer ear lengths, in comparison with the non-inoculated control. Kappes et al. (2013) also observed that the ear length was longer for plants grown from seeds inoculated with A. brasilense. Cavallet et al. (2000) found a $6 \%$ increase in ear length for plants that received seed inoculation with Azospirillum spp. In agreement with the present study, Ohland et al. (2005) and Kappes et

Table 3. Mean stem diameters measured at 30 and 60 days after sowing in a non-inoculated control maize plant and maize plants inoculated with Azospirillum brasilense strains Ab-V5 and Ab-V6 via seeds or leaf-spray at the V4 stage (Quirinópolis, Goiás State, Brazil, 2014).

\begin{tabular}{|c|c|c|c|c|c|}
\hline \multirow{3}{*}{ Inoculation } & \multicolumn{5}{|c|}{ Stem diameter $(\mathrm{cm})$} \\
\hline & \multicolumn{5}{|c|}{$\mathrm{N}$ doses } \\
\hline & $0 \%$ & $25 \%$ & $50 \%$ & $75 \%$ & $100 \%$ \\
\hline & & & 30 days & & \\
\hline Seeds & $25.60 \mathrm{Aa}$ & $25.26 \mathrm{Aa}$ & $25.40 \mathrm{Aa}$ & $25.93 \mathrm{Aa}$ & $26.55 \mathrm{Aa}$ \\
\hline Leaf-spray & $24.33 \mathrm{Ba}$ & $22.77 \mathrm{Ca}$ & $23.88 \mathrm{Ba}$ & $24.22 \mathrm{Ba}$ & $24.77 \mathrm{Ba}$ \\
\hline \multirow[t]{2}{*}{ Control } & $23.45 \mathrm{Ba}$ & $23.02 \mathrm{Ba}$ & $24.34 \mathrm{Aa}$ & $24.02 \mathrm{Ba}$ & $23.10 \mathrm{Ba}$ \\
\hline & & & 60 days & & \\
\hline Seeds & $27.33 \mathrm{Aa}$ & $27.88 \mathrm{Aa}$ & $28.88 \mathrm{Aa}$ & $28.00 \mathrm{Aa}$ & $28.66 \mathrm{Aa}$ \\
\hline Leaf-spray & $25.26 \mathrm{Aa}$ & $25.33 \mathrm{Aa}$ & $25.26 \mathrm{Aa}$ & $26.40 \mathrm{Aa}$ & $27.53 \mathrm{Aa}$ \\
\hline Control & $25.46 \mathrm{Aa}$ & $25.60 \mathrm{Aa}$ & $26.00 \mathrm{Aa}$ & $26.13 \mathrm{Aa}$ & $27.13 \mathrm{Aa}$ \\
\hline
\end{tabular}

Means followed by the same uppercase letter in the column and lower case letter in the line do not differ significantly from one another by the Tukey test at $5 \%$. Inoculations were applied in combination with cover doses of mineral $\mathrm{N}$ at the $\mathrm{V} 6$ stage, where $100 \%$ equals $50 \mathrm{~kg} \mathrm{ha}^{-1}$ as urea.

Table 4. Mean chlorophyll content and ear size measured at 60 days after sowing in a non-inoculated control maize plant and maize plants inoculated with Azospirillum brasilense strains Ab-V5 and Ab-V6 via seeds or leaf-spray at the V4 stage (Quirinópolis, Goiás State, Brazil, 2014).

\begin{tabular}{lccccc}
\hline \multirow{2}{*}{ Inoculation } & \multicolumn{5}{c}{$\mathrm{N} \mathrm{doses}$} \\
\cline { 2 - 5 } & $0 \%$ & \multicolumn{5}{c}{$50 \%$} & $75 \%$ & $100 \%$ \\
\hline \multirow{2}{*}{ Seeds } & $56.96 \mathrm{Ab}$ & Chlorophyll content (SPAD units) after 60 days & & \\
Leaf-spray & $55.46 \mathrm{Ab}$ & $60.06 \mathrm{Aa}$ & $60.25 \mathrm{Aa}$ & $60.76 \mathrm{Aa}$ & $60.07 \mathrm{Aa}$ \\
Control & $55.33 \mathrm{Ab}$ & $58.65 \mathrm{Aa}$ & $59.75 \mathrm{Aa}$ & $59.45 \mathrm{Ba}$ & $57.74 \mathrm{Ba}$ \\
\hline & & $57.68 \mathrm{Aa}$ & $57.94 \mathrm{Ba}$ & $57.74 \mathrm{Ba}$ \\
Seeds & $18.06 \mathrm{Aa}$ & $17.80 \mathrm{Aa}$ & $17.33 \mathrm{Aa}$ & $17.66 \mathrm{Aa}$ & $17.73 \mathrm{Aa}$ \\
Leaf-spray & $18.01 \mathrm{Aa}$ & $17.83 \mathrm{Aa}$ & $17.33 \mathrm{Aa}$ & $17.66 \mathrm{Aa}$ & $17.50 \mathrm{Aa}$ \\
Control & $15.46 \mathrm{Ba}$ & $16.00 \mathrm{Ba}$ & $15.80 \mathrm{Ba}$ & $16.73 \mathrm{Ba}$ & $16.06 \mathrm{Ba}$ \\
\hline
\end{tabular}

Means followed by the same uppercase letter in the column and lower case letter in the line do not differ significantly from one another using the Tukey test at $5 \%$. Inoculations were applied in combination with cover doses of mineral $\mathrm{N}$. 
al. (2013) verified that the application of $\mathrm{N}$ via foliage did not influence average ear length.

Nitrogen fertilization had a statistically significant effect (5\%) on the 1,000-grain weight $(\mathrm{g})$ and grain yield $\left(\mathrm{kg} \mathrm{ha}^{-1}\right)$. The regression analyses generated a linear fit for both traits, with different functions depending on the inoculation treatment (Figures $3 \mathrm{a}$ and $3 \mathrm{~b}$ ).

The highest yield was associated with the highest doses of nitrogen. Amaral Filho et al. (2005) verified that the increase in the $\mathrm{N}$ dose applied promoted an increase in foliar $\mathrm{N}$ content, number of grains per ear, 1,000-grain weight, yield and protein
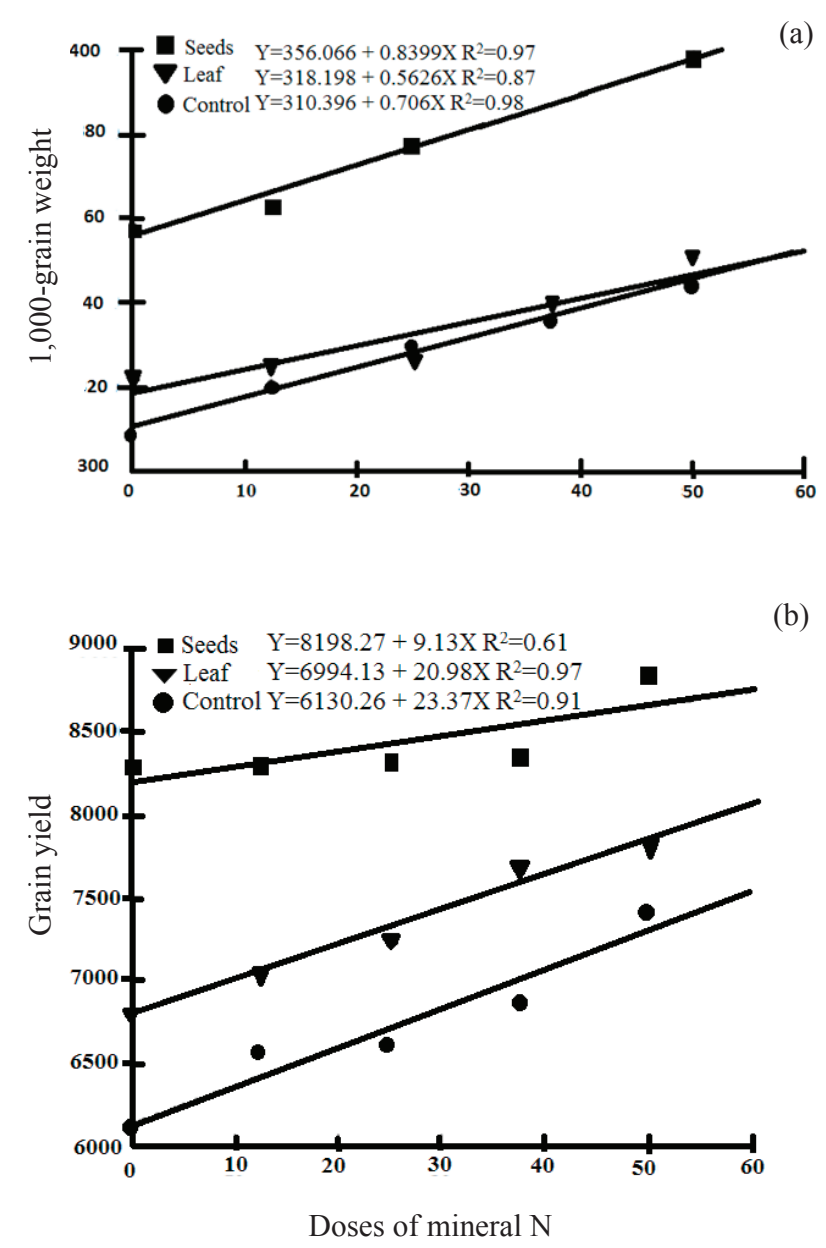

(b)

Figure 3. Regression analysis of the characteristics 1,000-grain weight (a) and grain yield (b) in response to different doses of $\mathrm{N}$-fertilizer after sowing in a non-inoculated control maize plant and maize plants inoculated with Azospirillum brasilense strains Ab-V5 and Ab-V6 via seeds or sprayed leaf-inoculation at the V4 stage (Quirinópolis, Goiás State, Brazil, 2014). Inoculations were applied in combination with cover doses of mineral $\mathrm{N}$. content of the grain. The highest grain yields were obtained with increasing $\mathrm{N}$ doses.

The inoculation of seeds with Azospirillum prior to sowing resulted in increased mass. Even with $0 \% \mathrm{~N}$ fertilization, the seed-inoculated treatment had a higher mass than that of the treatment that was not inoculated. Hungria et al. (2010) verified a $26 \%$ increase in grain yield for maize inoculated with Azospirilum, when compared to the control treatment. Oliveira \& Caires (2003) also found a linear increase in the 1,000-grain weight as a function of the increase in the $\mathrm{N}$ dosage, which resulted in superior grain yield.

A $36 \%$ increase in yield $\left(\mathrm{kg} \mathrm{ha}^{-1}\right)$ was verified when comparing the seed-inoculated treatment to the control with a $0 \% \mathrm{~N}$ dosage, and a $17 \%$ increase for the $100 \% \mathrm{~N}$ dose $\left(50 \mathrm{~kg} \mathrm{ha}^{-1}\right)$. There was an increase of $22 \%$ in the yield of the leaf-spray at the $\mathrm{V} 4$ treatment when the $\mathrm{N}$ dosage was $0 \%$, and an increase of $2.6 \%$ when the $\mathrm{N}$ dosage was $100 \%$ $\left(50 \mathrm{~kg} \mathrm{ha}^{-1}\right)$, in comparison with the control treatment.

Kappes et al. (2013) verified that the maize inoculated with Azospirilum showed a $9.4 \%$ increase in yield when compared to the control treatment. Cavallet et al. (2000) observed an increase of $30 \%$ when the seeds were inoculated and cover $\mathrm{N}$ had been applied. Martins et al. (2012) recorded a 7,490 $\mathrm{kg} \mathrm{ha}^{-1}$ yield for the control and $10,612 \mathrm{~kg} \mathrm{ha}^{-1}$ for inoculated plants, a $29 \%$ statistically significant increase from the non-inoculated plant. Cavallet et al. (2000) found that seeds inoculated with Azospirillum exhibited a $17 \%$ increase in yield. Novakowiski et al. (2011) observed similar results. Lana et al. (2012) found a $15 \%$ increase in the first harvest and $7 \%$ in the second. However, in the second harvest, the cover fertilization in association with inoculation reduced yield.

The regression analyses indicate a growing response to treatments with increasing doses of $\mathrm{N}$ for weight of 1,000 seeds. For grain yield, a diminished response of inoculation was observed in relation to the control treated with increasing $\mathrm{N}$ doses. However, it still presents a significant yield increase (Figure 3). Furthermore, for every $\mathrm{kg}$ of $\mathrm{N}$-fertilizer, there was an $8.5 \mathrm{~g}$ and $7.0 \mathrm{~g}$ increase in the 1,000-grain weight for the seed-inoculated treatments and leaf-sprayed inoculations at the V4 stage from the non-inoculated control, respectively. As for the grain yield, the addition of $1.0 \mathrm{~kg}$ of $\mathrm{N}$-fertilizer caused gains of $9.13 \mathrm{~kg} \mathrm{ha}^{-1}, 20.98 \mathrm{~kg} \mathrm{ha}^{-1}$ 
and $23.37 \mathrm{~kg} \mathrm{ha}^{-1}$, respectively for the seed-inoculated treatments, leaf-spray inoculation applied at the V4 stage and non-inoculated control.

The mean yields found in this research, where maize was inoculated with Azospirilum, are higher than the means for the Goiás State, which produced $6,448 \mathrm{~kg} \mathrm{ha}^{-1}$ in the first harvest and 6,579 $\mathrm{kg} \mathrm{ha}^{-1}$ in the second harvest of 2014/2015 (Conab 2015). This indicates its efficiency in increasing crop yield. However, the control treatment showed similar yield to the State means.

\section{CONCLUSIONS}

1. Azospirilum inoculation increases maize height and stem diameter, chlorophyll content and dry biomass weight for the shoot and root system, as well as 1,000-grain weight, ear length and grain yield, when the maize is inoculated via seed or leaf.

2. The effects of $\mathrm{N}$ fertilization are only visible in relation to 1,000-grain weight and grain yield $\left(\mathrm{kg} \mathrm{ha}^{-1}\right)$, and seed inoculations provide a higher yield in second-harvest maize.

\section{REFERENCES}

AMARAL FILHO, J. P. R. et al. Espaçamento, densidade populacional e adubação nitrogenada na cultura do milho. Revista Brasileira de Ciência do Solo, Viçosa, v. 29, n. 3, p. 467-473, 2005.

AYRES, M. et al. Aplicações estatísticas nas áreas das ciências biológicas e médicas: Sociedade Civil Mamirauá. 5. ed. Belém: Bioestat, 2007.

BARASSI, C. A. et al. Potencialidad de Azospirillum en optimizar el crecimiento vegetal bajo condiciones adversas. In: CASSÁN, F. D.; GARCÍA DE SALAMONE, I. (Eds.). Azospirillum sp.: cell physiology, plant interactions and agronomic research in Argentina. Buenos Aires: Asociación Argentina de Microbiologia, 2008. p. 49-59.

BASHAN, Y. et al. Azospirillum-plant relationships: physiological, molecular, agricultural, and environmental advances (1997-2003). Canadian Journal of Microbiology, Ottawa, v. 50, n. 8, p. 521-577, 2004.

BRACCINI, A. L. et al. Seed inoculation with Azospirillum brasilense, associated with the use of bioregulators in maize. Revista Caatinga, Mossoró, v. 25, n. 2, p. 58-64, 2012.

CAVALLET, L. E. et al. Produtividade do milho em resposta à aplicação de nitrogênio e inoculação das sementes com Azospirillum spp. Revista Brasileira de
Engenharia Agrícola e Ambiental, Campina Grande, v. 4, n. 1, p. 129-132, 2000.

COMPANHIA NACIONAL DE ABASTECIMENTO (Conab). Acompanhamento da safra brasileira de grãos: safra 2014/15. 2015. Disponível em: < http://www.conab. gov.br/OlalaCMS/uploads/arquivos/15 $01 \quad 09 \quad 09 \quad 0$ 0_21_boletim_graos_janeiro_2015.pdf $>$. Acesso em: mai. 2015.

CORRÊA, O. S. et al. Azospirillum brasilense - plant genotype interactions modify tomato response to bacterial diseases, and root and foliar microbial communities. In: CASSÁN, F. D.; GARCÍA DE SALAMONE, I. (Eds.). Azospirillum sp.: cell physiology, plant interactions and agronomic research in Argentina. Buenos Aires: Asociación Argentina de Microbiologia, 2008. p. 87-95.

DALLA SANTA, O. R. et al. Azospirillum sp. inoculation in wheat, barley and oats seeds in greenhouse experiments. Brazilian Archives of Biology and Technology, Curitiba, v. 47, n. 6, p. 843-849, 2004.

DARTORA, J. et al. Influência do tratamento de sementes no desenvolvimento inicial de plântulas de milho e trigo inoculados com Azospirillum brasilense. Scientia Agraria Paranaensis, Marechal Cândido Rondon, v. 12, n. 3, p. 175-181, 2013.

DOBBELAERE, S. C. A. et al. Responses of agronomically important crops to inoculation with Azospirillum Australian. Journal of Plant Physiology, Hobart, v. 28, n. 9, p. 871-879, 2001.

DOMINGUES NETO, F. J. et al. Desenvolvimento e produtividade do milho verde safrinha em resposta à aplicação foliar com Azospirillum brasilense. Enciclopédia Biosfera, Goiânia, v. 9, n. 17, p. 1030-1040, 2013.

DOTTO, A. P. et al. Produtividade do milho em resposta à inoculação com Herbaspirillum seropedicae sob diferentes níveis de nitrogênio. Revista Brasileira de Ciências Agrárias, Recife, v. 5, n. 3, p. 376-382, 2010.

EMPRESA BRASILEIRA DE PESQUISA AGROPECUÁRIA (Embrapa). Centro Nacional de Pesquisa de Solos. Sistema brasileiro de classificação de solos. 3. ed. Rio de Janeiro: Embrapa-CNPS, 2013.

HUNGRIA, M. et al. Inoculation with selected strains of Azospirillum brasilense and A. lipoferum improves yields of maize and wheat in Brazil. Plant and Soil, Amsterdam, v. 331, n. 1-2, p. 413-425, 2010.

KAPPES, C. et al. Inoculação de sementes com bactéria diazotrófica e aplicação de nitrogênio em cobertura e foliar em milho. Semina: Ciências Agrárias, Londrina, v. 34, n. 2, p. 527-538, 2013.

LANA, M. do C. et al. Inoculation with Azospirillum, associated with nitrogen fertilization in maize. Revista Ceres, Viçosa, v. 59, n. 3, p. 399-405, 2012. 
MARTINS, F. A. D. et al. Avaliação de híbridos de milho inoculados com Azospirilum brasilense. Pesquisa Agropecuária Gaúcha, Porto Alegre, v. 18, n. 2, p. 103110, 2012.

MOREIRA, F. M. de S. et al. Bactérias diazotróficas associativas: diversidade, ecologia e potencial de aplicações. Comunicata Scientiae, Teresina, v. 1, n. 2, p. 74-99, 2010.

NOVAKOWISKI, J. H. et al. Efeito residual da adubação nitrogenada e inoculação de Azospirillum brasilense na cultura do milho. Semina: Ciências Agrárias, Londrina, v. 32, n. 4, p. 1687-1698, 2011.

OHLAND, R. A. A. et al. Culturas de cobertura do solo e adubação nitrogenada no milho em plantio direto. Ciência e Agrotecnologia, Lavras, v. 29, n. 3, p. 538-544, 2005.

OLIVEIRA, J. M. S.; CAIRES, E. F. Adubação nitrogenada em cobertura para o milho cultivado após aveia preta no sistema plantio direto. Acta Scientiarum Agronomy, Maringá, v. 25, n. 2, p. 351-357, 2003.

PIEKIELEK, W. P. et al. Use of a chlorophyll meter at the early dent stage of corn to evaluate $\mathrm{N}$ sufficiency. Agronomy Journal, Madison, v. 87, n. 3, p. 403-408, 1995.

RAMOS, A. S. et al. Ação do Azospirillum lipoferum no desenvolvimento de plantas de milho. Revista Verde, Mossoró, v. 5, n. 4, p. 113-117, 2010.

ROESCH, L. F. W. et al. Characterization of diazotrophic bacteria associated with maize: effect of plant genotype, ontogeny and nitrogen-supply. World Journal of Microbiology \& Biotechnology, Dordrecht, v. 22, n. 9, p. 967-974, 2006.

SANTOS, G. C. et al. Caracterização geoambiental do município de Quirinópolis. In: URZEDO, M. da F. A. (Org.). Quirinópolis, mãos e olhares diferentes: 19322010. Goiânia: Kelps, 2010. p. 251-266. 